\title{
Effects of experimental lightgaps and topography on enrichment plantings in a central Amazonian secondary forest
}

\author{
Tony Vizcarra BENTOS ${ }^{1 *}$ (D) Henrique E. M. NASCIMENTO ${ }^{1}$, Marisângela dos Anjos VIZCARRA ${ }^{1}$, \\ G. Bruce WILLIAMSON ${ }^{2}$ \\ Instituto Nacional de Pesquisas da Amazônia-INPA, Coordenação de Biodiversidade, Av. André Araújo 2936, CEP 69067-375 Manaus, Amazonas, Brazil \\ 2 Louisiana State University, Department of Biological Sciences, Baton Rouge, LA 70803-1705, USA \\ * Corresponding author: vbtonyco@gmail.com; D https://orcid.org/0000-0002-4673-956X
}

\begin{abstract}
Enrichment plantings into secondary forest are an important option in restoring species diversity and ecosystem services. However, little attention has been given to environmental requirements for species performance. This study evaluated the effects of lightgaps and topographic position on the growth and survival of four native tree species (Pouteria caimito, Garcinia macrophylla, Dipteryx odorata and Cynometra bauhiniaefolia) planted into a 26-year old secondary forest originating from abandoned pastures in the central Amazon Basin. Artificial lightgaps and control plots under closed canopy were uniformly distributed on plateaus and bottomlands near water bodies. Seedlings were planted randomly into the plots and monitored for 28 months. Seedling survival rate was high (93\%) and did not differ among species. Overall, lightgaps produced a 38\% increase in seedling height relative to the controls. Although the four species naturally occur in mature forest, two of the four grew significantly more in lightgaps than in closed canopy secondary forest. Overall, bottomlands facilitated greater seedling growth in height (38\%) relative to plateaus, but only one species exhibited a significant increase. This study shows the importance of the environmental variability generated with canopy openings along the topographic gradient, suggesting that both the selection of species and microsite conditions of planting sites have to be considered important criteria in the recovery of degraded areas.
\end{abstract}

KEYWORDS: abandoned pastures, environmental conditions, height growth, light availability

\section{Efeitos de clareiras experimentais e da topografia sobre plantios de enriquecimento em uma floresta secundária na Amazônia central}

\section{RESUMO}

O plantio de enriquecimento em florestas secundárias é uma opção para restaurar a diversidade de espécies e os serviços ecossistêmicos. No entanto, pouca atençáo tem sido dada aos requerimentos ambientais para o melhor desempenho das espécies. Este estudo avaliou os efeitos de clareiras e posição topográfica sobre o crescimento e sobrevivência de quatro espécies arbóreas nativas (Pouteria caimito, Garcinia macrophylla, Dipteryx odorata and Cynometra bauhiniaefolia) plantadas em florestas secundárias oriundas de pastagens abandonadas há 26 anos na Amazônia central. Clareiras artificiais e parcelas de controle sob dossel fechado foram distribuídos uniformemente em platôs e baixios. Mudas foram plantadas aleatoriamente nas parcelas e monitoradas por 28 meses. A taxa de sobrevivência das plântulas foi alta (93\%) e não houve diferenças entre as espécies. Entre todas as espécies, houve um incremento de 38\% na altura das plântulas em comparação com os controles. Embora as quatro espécies ocorram naturalmente em florestas maduras, duas das quatro cresceram significativamente mais em clareiras do que sob dossel fechado. Entre todas as espécies, plântulas tiveram um maior crescimento em altura (38\%) nos baixios que nos platôs, mas apenas uma espécie apresentou um aumento significativo. Este estudo mostra a importância da variabilidade ambiental gerada com aberturas do dossel ao longo do gradiente topográfico, sugerindo que, tanto a seleção de espécies como as condiçóes microambientais deveriam ser considerados como critérios importantes na recuperação de áreas degradadas.

PALAVRAS-CHAVE: pastagens abandonadas, condiçóes ambientais, crescimento em altura, disponibilidade de luz 


\section{INTRODUCTION}

In the Brazilian Amazon, despite efforts to control the advance of deforestation, extensive areas continue to be clearcut and converted to various anthropogenic land uses. The principal factors behind the increase are the illegal extraction of timber and forest conversion to pastures and other land uses. However, most pastures are abandoned in a short period of time due to low productivity related to inadequate management and low natural soil fertility (EMBRAPA/INPE 2014). Pastures are the predominant land use in Amazonia and the activity with greatest impact on forest recovery, due to soil compaction by cattle and to prescribed annual fires that reduce natural ecosystem resilience (Uhl et al. 1988; Lucas et al. 1998; Mesquita et al. 2001). Forests regenerating from abandoned pastures are characterized by low biodiversity and slow species replacements relative to areas clearcut and abandoned without conversion to pasture (Williamson et al. 2012; Longworth et al. 2014; Mesquita et al. 2015). In this scenario of impeded succession, intervention with adequate management is considered one of the principal methods for forest restoration on abandoned pastures (Lamb et al. 2005; Norden et al. 2010).

One intervention method to promote succession is the introduction of mature forest species into the depauperate secondary forests dominated by Vismia (Jakovac et al. 2012). Despite various examples of planting to enrich tropical secondary forests (e.g., Evans and Turnbull 2004; Romell $e t$ al. 2008; Jakovac et al. 2012), definitive conclusions regarding different treatments and optimal conditions for planting are elusive, as they depend on the variability in natural environments and species-specific requirements (BenitezMalvido et al. 2005; Yavitt and Wright 2008).

In classical secondary succession of tropical wet forests, the availability of light decreases with time as the arboreal canopy closes and the sub-canopy vegetation stratifies (Capers et al. 2005; Chazdon 2008). Thus, the formation of lightgaps, occurring naturally from treefalls, is an important mechanism for maintaining biodiversity and forest dynamics through creation of heterogeneity in light availability in understory patches (Brokaw 1985; Denslow 1987; Whitmore 1989). Nevertheless, natural lightgaps in secondary forests tend to be relatively small and infrequent, so that light is a limiting resource for recruitment of seedlings and saplings (Saldarriaga et al. 1988; Yavitt et al. 1995; Montgomery and Chazdon 2001; Bebber et al. 2002; Balderrama and Chazdon 2005; Dupuy and Chazdon 2006; Dupuy and Chazdon 2008). Studies of secondary forests originating on abandoned pasturelands in the central Amazon Basin revealed the benefits of artificial lightgaps in recruitment and growth of natural vegetation (Bentos et al. 2013), as well as changes in species composition after six years of natural regeneration (Bentos et al. 2017).
In primary forests of the central Amazon, topography exerts a strong influence on plant species distributions and vegetation structure as a result of variation in the physical and chemical properties of soils (Costa et al. 2005; Bohlman et al. 2008). Soils on elevated plateaus generally have high clay content and extremely low levels of nutrients, whereas soils in the bottomlands near water sources have high sand content and slightly higher nutrient levels due to accumulation of organic matter (Luizão et al. 2004; Toledo et al. 2011). Differences in the physical and chemical properties of the soil linked to the topographic variation were not determinant of the floristic composition in secondary forest (Bentos et al. 2017). Although plateaus are presumed to receive more light than bottomlands, Bentos et al. (2013) showed that the recruitment and growth of seedlings emerging from the seed bank in artificial lightgaps was higher in bottomlands.

In this study we ask what effects these two factors, lightgaps and topography, have on survival and growth of four potential enrichment species planted in secondary forests dominated by Vismia in the central Brazilian Amazon.

\section{MATERIAL AND METHODS}

\section{Study area}

The study was conducted at the Esteio ranch research area of the Biological Dynamics of Forest Fragments Project (BDFFP) $\left(2^{\circ} 30^{\prime} \mathrm{S}, 60^{\circ} \mathrm{W}\right)$, located $80 \mathrm{~km}$ north of Manaus, Amazonas, Brazil. Climate in the study area is $A f$, tropical humid, in the Köppen classification, with an average annual temperature of $27^{\circ} \mathrm{C}$ and precipitation between 1900 and $3500 \mathrm{~mm}$ per year, with higher rainfall occurring from February to April (Alvares et al. 2013). Soils are clays, classified as yellow latosols (Ultisol) and red-yellow podozols (Oxisol) (Ranzani 1980). In general, the soils are acidic and poor in nutrients, especially phosphorous, calcium, magnesium, sodium and potassium (Chauvel et al. 1987; Toledo et al. 2011). The topography of the region is of gently rolling hills, characterized by upland plateaus, slopes and bottomlands, at elevations of 40-140 m.a.s.l. Soil properties follow topography with high clay content on the plateaus and high sand content in the bottomlands (Chauvel et al. 1987; Toledo et al. 2011).

The BDFFP research area contains replicated forest fragments of 1,10 or 100 ha. The fragments were isolated in the early 1980's after the mature forest was cleared for agronomic activity, mainly pastures (Lovejoy and Bierregaard 1990). Following 4-5 years of cattle grazing and annual prescribed burning to maintain the grassland, pastures were gradually abandoned because of decreased productivity. Forest regeneration commenced in abandoned pastures with scattered patches of trees, mostly Vismia species that had survived the fires. This study was conducted in the abandoned pastures dominated by Vismia. 


\section{Experimental lightgaps}

Fourteen experimental lightgaps (10 x 10-m plots) were created in the Esteio ranch in April 2009, near the end of the rainy season, in an $8-\mathrm{km}^{2}$ area of 20 -year old secondary forest with a closed canopy dominated by Vismia species. The plots were located at least $200 \mathrm{~m}$ apart to avoid interdependence. In each plot, the composition of the vegetation was recorded, and in May 2009 all vegetation was removed from the plots, including seedlings, trees and vines, as well as coarse woody debris. Adult plants were cut at the base of the trunk with a chainsaw, while small individuals were cut with a machete. The 14 plots were distributed uniformly among two topographic positions, plateaus and bottomlands [see Bentos et al. (2013) for more details on the study area and experimental design].

In March 2015, the plots were cleared a second time by removing vegetation that had regenerated since lightgap creation six years earlier. The regeneration had reached $3 \mathrm{~m}$ in height, and plant composition had changed somewhat from the initial 2009 census (Bentos et al. 2017). In the surrounding secondary forest, now 26 years old and still strongly dominated by Vismia species, eight new $10 \times 10-\mathrm{m}$ plots were established as closed canopy controls, four on plateau and four on bottomland.

\section{Planting of seedlings}

Considering the low tree species diversity and high dominance of pioneer species in abandoned pasture areas, even after two decades of secondary succession, four nonpioneer, native species with economic potential were selected for the experimental enrichment plantings in the lightgaps. These species are considered typical 'climax' species of primary forests and are not often recorded in natural regeneration in these areas. Therefore, the selection of species from a single functional group aimed to evaluate whether canopy opening and topographic variation influence species performance. The selected species are commonly utilized in agroforestry systems, with long lives, slow growth, relatively high wood densities $\left(0.75-0.92 \mathrm{~g} \mathrm{~cm}^{-3}\right)$ and varied seed weight (1.06 - 3.5 g) (Benitez-Malvido et al. 2005; Zau et al. 2014). Pouteria caimito (Ruiz \& Pav.) Randlk. (locally known as abiü) (Sapotaceae) and Garcinia macrophylla Mart. (bacuri) (Clusiaceae), are recognized as potential fruit trees for human consumption (fruiting starts between three and five, and four and eight years, respectively) (Falcáo and Clement 1999; Xavier et al. 2001). Dipteryx odorata (Aubl.) Willd. (cumaru) (Fabaceae) is a well-known timber species, which starts fruiting between six and nine years (Barbosa et al. 2003). Cynometra bauhiniaefolia Benth. (jutairana) (Fabaceae) has no economic use identified as yet, but other tree species of the same genus are used in carpentry, joinery, and charcoal production (Tavares 1987). Recently, the species is utilized in urban forestry in tropical wet biomes across Brazil and it starts fruiting between five and eight years (Tavares and Silva 1992; Nazário et al. 2008).

A total of 232 seedlings were planted in the 14 26-year old lightgaps and eight controls in March 2015. The seedlings were produced in a greenhouse from seeds obtained from matrices in a neighboring primary forest site. After sowing and germination, the seedlings were kept in the greenhouse for two years. In each lightgap plot, 12 seedlings were planted, three of each species. In each control plots, only two seedlings of each species were planted, due to the limited number of seedlings. To ensure exposure to incident light, the seedlings were planted in the central portion of each plot, at least $1 \mathrm{~m}$ from one another. Each seedling was planted into a 40 x $40 \mathrm{x}$ $40-\mathrm{cm}$ hole that was refilled with the same excavated soil. Any understory regeneration around the seedlings was removed to prevent competition. Planting procedures were the same in lightgap and control plots, except there was no understory regeneration to remove in the control plots.

Seedling height was recorded as the vertical distance from the soil surface to the highest apical meristem, not to the highest portion of the highest leaf. At the time of planting, the mean apical height was $52.9 \pm 0.04 \mathrm{~cm}($ mean \pm SE) for P. caimito, $46.0 \pm 0.04 \mathrm{~cm}$ for D. odorata, $40.9 \pm 0.03 \mathrm{~cm}$ for C. bauhiniaefolia and $40.6 \pm 0.03 \mathrm{~cm}$ for G. macrophylla. The initial height used in analysis of growth was recorded one month after planting, to allow for acclimation changes. The final height was recorded 28 months after the initial height (July 2017). Relative height growth (RGH) was calculated as final height minus initial height, divided by the initial height.

\section{Data analysis}

Three-way analysis of variance (ANOVA) was employed to test for effects of species, canopy condition and topographic position on the dependent variable, RHG, among the four species (P. caimito, C. bauhiniaefolia, G. macrophylla and $D$. odorata), two canopy conditions (lightgap and control) and two topographic positions (plateau and bottomland). RHG was log transformed to reach normality and reduce heteroscedasticity before the ANOVA was performed in SYSTAT 12.0 (Wilkinson 2007).

\section{RESULTS}

Of the 232 seedlings, only $16(7 \%)$ died over the 28 months. Ten died in the plateau plots, seven of 84 in lightgaps and three of 32 in control plots. Six died in bottomlands, four of 84 in lightgaps and two of 32 in control plots. Pouteria caimito and C. bauhiniaefolia suffered the most deaths (seven of 58, and five of 58 seedlings, respectively), while $G$. macrophylla and $D$. odorata lost only two individuals each.

In contrast to seedling survival, RHG varied significantly between canopy conditions $\left(F_{1.71}=14.93, p<0.001\right)$ and topographic positions $\left(F_{1,71}=4.28, p=0.042\right)$. RHG was 
higher in lightgaps (mean $\pm \mathrm{SE}=0.282 \pm 0.023 \mathrm{~cm} \mathrm{~cm}^{-1}$ ) than in controls $(0.204 \pm 0.024)$, and higher in bottomlands $(0.295 \pm 0.027)$ than in plateaus $(0.214 \pm 0.021)$ (Figure 1). It is noteworthy that, despite the difference in statistical significance, the magnitude of the increase in RHG was the same for lightgaps (38\%) and bottomlands (38\%). The statistical difference may be due to the nature of our unbalanced experimental design. The interaction effect between canopy condition and topographic position was non-significant $\left(F_{1,71}=0.22, p=0.64\right)$.

RGH also varied significantly among species $\left(F_{3,71}=16.32\right.$, $p<0.001)$. The RHG of G. macrophylla was significantly lower (mean $\left.\pm \mathrm{SE}=0.097 \pm 0.021 \mathrm{~cm} \mathrm{~cm}^{-1}\right)$ than that of $C$. bauhiniaefolia $(0.250 \pm 0.037)$, P. caimito $(0.264 \pm 0.044)$ and $D$. odorata ( $0.406 \pm 0.052$ ) (Tukey's test, $p<0.001$ for each comparison). There was no significant difference among the latter three species $(p>0.3)$. Although there was no significant interaction between topography and species $\left(F_{3,71}\right.$ $=0.58, p=0.632)$, the interaction of canopy condition and species was highly significant $\left(F_{3,71}=4.29, p=0.008\right)$. As there were differences among species in the three-way ANOVA, a two-way ANOVA was performed for each species separately. Canopy condition had a significant effect on growth of $P$. caimito $\left(F_{1,18}=6.29, p=0.023\right)$ and $G$. macrophylla $\left(F_{1,18}=\right.$ 13.94, $p=0.002)$, but not on $D$. odorata $\left(F_{1,18}=2.44, p=\right.$ $0.136)$ and C. baubiniaefolia $\left(F_{1,18}=1.07, p=0.315\right)$. The $\mathrm{RGH}$ of $P$. caimito was higher in lightgaps (mean $\pm \mathrm{SE}=$ $\left.0.319 \pm 0.052 \mathrm{~cm} \mathrm{~cm}^{-1}\right)$ than in control plots $(0.155 \pm 0.070)$, and was also higher in lightgaps for G. macrophylla $(0.128 \pm$ $0.026)$ than in the controls $(0.043 \pm 0.028)$ (Figure 2a). In contrast, topographic position had a significant effect only on C. baubiniaefolia $\left(F_{1,18}=4.37, p=0.051\right)$, with RHG higher in the bottomlands $(0.329 \pm 0.059)$ than on the plateaus

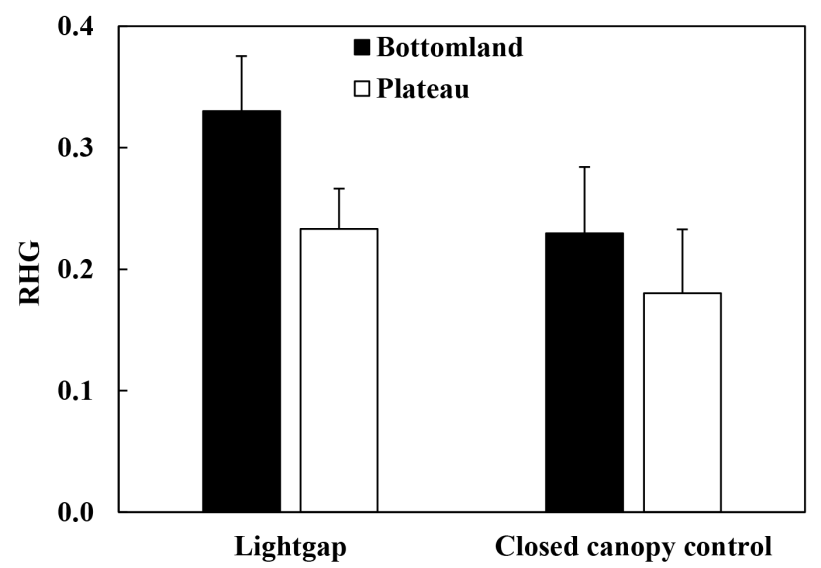

Figure 1. Overall relative height growth (RHG in $\mathrm{cm} \mathrm{cm}^{-1}$ ) of seedlings of four native tree species over 28 months as a function of canopy condition (lightgap vs. closed canopy control) and topographic position (plateau vs. bottomland) in secondary forest in the central Amazon. Columns indicate the mean and bars the standard error of the mean.
$(0.170 \pm 0.033)$ (Figure 2b). The other three species showed no significant effect of topographic position $\left(F_{1,18}<1.66, p>\right.$ 0.222 for all cases) (Figure $2 \mathrm{~b}$ ).

\section{DISCUSSION}

Irrespective of light conditions (lightgap or closed canopy) and topographic variation, the planted seedlings had high survival rates, but RHG was higher overall in lightgaps and bottomlands, despite variable responses among species. The lightgaps clearly revealed the importance of light availability to seedling growth, even though the species tested are considered typical of mature forests and capable of surviving under secondary-forest closed canopy. The higher growth in the bottomlands was probably related to greater water and nutrient availability in the soil.

The high survival rates indicate that the canopy opening and topographic conditions were not limiting in the evaluated

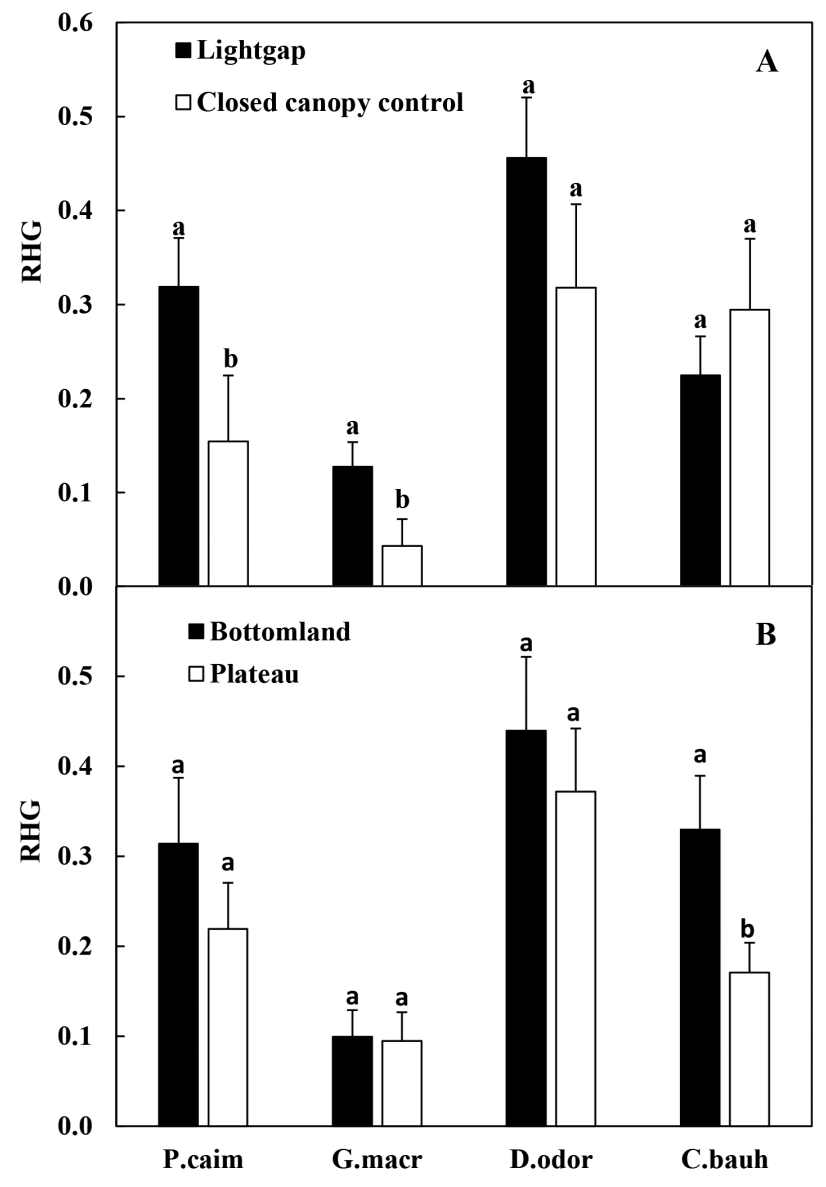

Figure 2. Relative height growth (RHG in $\mathrm{cm} \mathrm{cm}^{-1}$ ) of seedlings of four species (P.caim $=$ Pouteria caimito, G.macr $=$ Garcinia macrophylla, D.odor $=$ Dipteryx odorata, C.bauh = (ynometra bauhiniaefolia) over 28 months in a secondary forest in the central Brazilian Amazon as a function of canopy condition (lightgap vs. closed canopy control) (A), and topographic position (plateau vs. bottomland) (B). Columns indicate the mean and bars the standard error of the mean. Different letters above the bars indicate significant differences $(p \leq 0.05)$. 
phase of seedling development and that the test species were tolerant to the range of environmental conditions to which they were exposed, which may have been favored by the headstart period of the seedlings in the greenhouse prior to planting. Previous studies show that both canopy opening (Denslow 1987; Peña-Claros 2002) and the quality of light that reaches the forest understory (Chazdon and Pearcy 1991; Leakey et al. 2003) are the most important factors for survival and growth of non-pioneer species in tropical secondary forests.

Despite the functional and phenological similarities among the species studied (long-lived, slow-growing, largeseeded mature forest species), they responded differently to lightgaps and topography. Although non significantly, $C$. bauhiniaefolia was the only species exhibiting higher growth in the closed-canopy control plots, possibly because light availability was less limiting to it than to the other species. In addition, RHG of $C$. baubiniaefolia was significantly higher in the bottomlands, and mortality (two of seven) was mostly in the lightgaps, suggesting a preference of this species for more shaded and humid habitats. It is commonly found in seasonally-flooded, mature floodplain forests (Tavares and Silva 1992; Wittmann et al. 2010).

Garcinia macrophylla, which had the lowest RHG among the species, presents a wide geographic distribution, as a result of its adaptation to various types of soil and climate (Flora do Brasil 2020). Some species of Garcinia are water-demanding fruit-bearing trees that are cultivated in the shade, but they may tolerate direct sunlight well due to their leaf characteristics (large and glabrous leaves) that enhance hydric stress tolerance (Xavier et al. 2001). However, even though its RHG was significantly higher in the lightgaps, many leaves became yellowish, probably as a result of water deficit, especially in the dry season, although its mortality was quite low. Its RHG varied little between plateau and bottomland, which reflects the adaptability of G. macrophylla, that is commonly found in both floodplain and terra-firme forests across the Amazon basin (Tavares and Silva 1992).

On average, the RHG of $D$. odorata was higher than that of the other species. Uchida and Campos (2000) evaluated the effect of zero to $70 \%$ shading on initial growth of $D$. odorata under greenhouse conditions, and found no significant variation among shading levels. They suggest that $D$. odorata may exhibit foliar anatomical plasticity in different shading conditions, thereby facilitating high survival and growth in degraded environments such as secondary forests. In our study, the non-significant variation between plateau and bottomland suggests as well that the species tolerates a range of soil conditions (water and nutrients) associated with topography.

The RHG of $P$. caimito was significantly higher in the lightgaps than in control plots, corroborating the findings of Benitez-Malvido et al. (2005), who showed that P. caimito grew faster in more open sites with high photosynthetically active radiation. It has been suggested that species with large seeds, such as $P$. caimito, have better tolerance to adverse conditions in open areas and pastures, as large seeds tend to generate seedlings with large cotyledons that function as storage organs, rich in resources, thereby facilitating survival and growth (Benítez-Malvido and Kossmann-Ferraz 1999).

An earlier study at the same sites monitored species richness and composition before and six years after lightgap creation and also registered significant effects of canopy opening on seedlings regenerating from the seed bank (Bentos et al. 2017). Seedling recruitment in lightgaps showed a significant increase in species richness, particularly among non-pioneer, forest species (Bentos et al. 2017). A parallel increase in species richness of saplings occurred but this could have been owed to the increase in stem density of saplings in the lightgaps. This increase in species richness suggests that enrichment plantings may be less essential for forest restoration where artificial lightgaps receive adequate seed rain from nearby mature forest. The BDFFP study sites of Bentos et al. (2017) and this study are surrounded by a matrix of mature forests, so that seeds of shade-tolerant species are expected to be dispersed into the secondary forest plots. Therefore, the need for enrichment plantings may increase as secondary forests become further removed from mature-forest seed sources.

The variation in light among experimental plots, with and without clearing, did not affect significantly the RHG of species native to young Vismia secondary forest in a site $60 \mathrm{~km}$ west of ours (Jakovac et al. 2012). This contrasting result may be related to the different age of the secondary forests studied by Jakovac et al. (2012) (5-16 years) and Bentos et al. (2017) (26 years), as well as to the proportion of basal area removed to open the canopy (35\% and $100 \%$, respectively). Further studies should focus on both the age of secondary forests and the degree of canopy removal to determine conditions for different restoration methods.

Seedling survival was high across species and topographic position in our study. However, bottomlands, likely due to greater soil moisture and more nutrients, afforded significantly higher RHG than plateaus. An earlier study to evaluate natural recruitment and initial growth from the seed bank showed a parallel effect of greater height growth in bottomlands than in plateaus, although there was no difference in the density of seeds germinating in the two locations (Bentos et al. 2013). The nature of growth facilitation in bottomlands may be tested in future studies by experimentally manipulating water and nutrient levels at different topographic positions.

\section{CONCLUSIONS}

Our study highlights the importance of the creation of artificial lightgaps to enhance the survivorship and growth of seedlings through increased light levels. Growth is also 
favored in bottomlands relative to plateaus, possibly due to higher water and nutrient availability. The choice of species with different functional traits for enrichment planting should be taken into consideration in order to take advantage of the environmental variability. Species adapted to poorer and drier soils could be planted on plateaus, and high-demanding species in more fertile and humid soils in bottomlands.

\section{ACKNOWLEDGMENTS}

This research is part of TVB's project of Programa de Fixação de Doutores no Estado do Amazonas (FIXAM-AM, process \# 062.02273/2014) and Programa de Capacitaçáo Institucional of Instituto Nacional de Pesquisas da Amazônia (INPA). Financial support was provided by Fundação de Amparo à Pesquisa do Estado do Amazonas - FAPEAM (Brazil). TVB acknowledges also the financial support of Conselho Nacional de Desenvolvimento Científico e Tecnológico - CNPq (Brazil) (process \# 301481/2020-2). GBW was supported by the US National Science Foundation (DEB-1147434). We thank Cícero and Alaércio Marajó for excellent field assistance. This is publication \# 793 of the technical series of the Biological Dynamics of Forest Fragments Project (PDBFF-INPA).

\section{REFERENCES}

Alvares, C.A.; Stape, J.L.; Sentelhas, P.C.; de Moraes, G.; Leonardo, J.; Sparovek, G. 2013. Köppen's climate classification map for Brazil. Meteorologische Zeitschrift. 22: 711-728.

Barbosa, A.P.; Iida, S.; Vieira, G.; Sampaio, P.T.B.; Oliveira, L.A.; Campos, M.A.A.; et al. 2003. Silvicultura tropical e a recuperação de áreas degradadas pela agricultura itinerante na Amazônia Central. In: Higuch, N.; Santos, J.; Sampaio, P.T.B. (Ed.). Projeto jacarandá Fase II: Pesquisas florestais na Amazônia Central. Editora INPA, Manaus, p.223-239.

Balderrama, S.I.V.; Chazdon, R.L. 2005. Light-dependent seedling survival and growth of four tree species in Costa Rican secondgrowth rain forests. Journal of Tropical Ecology, 21: 383-395.

Bebber, D.; Brown, N.; Speight, M.; Moura-Costa, P.; Wai, Y.S. 2002. Spatial structure of light and dipterocarp seedling growth in a tropical secondary forest. Forest Ecology and Management, 157: 65-75.

Bentos, T.V.; Nascimento, H.E.M.; Williamson, G.B. 2013. Tree seedling recruitment in Amazon secondary forest: Importance of topography and gap micro-site conditions. Forest Ecology and Management, 287: 124-131.

Bentos, T.V.; Nascimento, H.E.M.; Vizcarra dos Anjos, M.; Williamson, G.B. 2017. Effects of lightgaps and topography on Amazon secondary forest: changes in species richness and community composition. Forest Ecology and Management, 396: 140-146.

Benitez-Malvido, J.; Martínez-Ramos, M.; Camargo, J.L.C.; Ferraz, I.D.K. 2005. Responses of seedling transplants to environmental variations in contrasting habitats of central Amazonia. Journal of Tropical Ecology, 21: 397-406.
Benitez-Malvido, J.; Kossmann-Ferraz, I.D.K. 1999. Litter cover variability affects seedling performance and herbivory. Biotropica, 31: 598-606.

Bohlman, S.A.; Laurance, W.F.; Laurance, S.G.; Nascimento, H.E.M.; Fearnside, P.M.; Andrade, A. 2008. Importance of soils, topography and geographic distance in structuring central Amazonian tree communities. Journal of Vegetation Science, 19:863-874.

Brokaw, N.V.L. 1985. Gap-phase regeneration in a tropical forest. Ecology, 66: 682-687.

Capers, R.S.; Chazdon, R.L.; Brenes, A.R.; Alvarado, B.V. 2005. Successional dynamics of woody seedling communities in wet tropical secondary forests. Journal of Ecology, 93: 1071-1084.

Chauvel, A.; Lucas, Y.; Boulet, R. 1987. On the genesis of the soil mantle of the region of Manaus, Central Amazonia, Brazil. Experientia, 43: 34-241.

Chazdon, R.L.; Pearcy, R.W. 1991. The importance of sunflecks for forest understorey plants. Bioscience 41: 760-766.

Chazdon, R.L. 2008. Chance and determinism in tropical forest succession. In: Carson, W.; Schnitzer, S. (Ed.). Tropical Forest Community Ecology. Wiley-Blackwell Publishing, Oxford, p.384-408.

Costa, F.R.C.; Magnusson, W.E.; Regina, C.L. 2005. Mesoscale distribution patterns of Amazonian understorey herbs in relation to topography, soil and watersheds. Journal of Ecology, 93:863-878.

Denslow, J.S. 1987. Tropical rainforest gaps and tree species diversity. Annual Review of Ecology Systematics, 18: 431-4521.

Dupuy, J.M.; Chazdon, R.L. 2006. Effects of vegetation cover on seedling and sapling dynamics in secondary tropical wet forests in Costa Rica. Journal of Tropical Ecology, 22: 65-76.

Dupuy, J.M.; Chazdon, R.L. 2008. Interacting effects of canopy gap, understory vegetation and leaf litter on tree seedling recruitment and composition in tropical secondary forests. Forest Ecology and Management, 255: 3716-3725.

EMBRAPA/INPE. 2014. Empresa Brasileira de Pesquisa Agropecuária e Instituto Nacional de Pesquisas Espaciais. TerraClass. Levantamento de informaçôes de uso e cobertura da terra na Amazônia. Sumário Executivo.

Evans, J.; Turnbull, J. 2004. Plantation Forestry in the Tropics. Oxford University Press, Oxford.194p.

Falcão, M.A.; Clement, C.R. 1999. Fenologia e Produtividade do Abiu (Pouteria caimito) na Amazônia central. Acta Amazonica, 29:3-11.

Flora do Brasil 2020 em construção. Jardim Botânico do Rio de Janeiro (http://floradobrasil.jbrj.gov.br/). Acessed on 29 Jan 2020.

Jakovac, A.C.C.; Bentos, T.V.; Mesquita, R.C.G.; Williamson, G.B. 2012. Age and light effects on seedling growth in two alternative secondary successions in central Amazonia. Plant Ecology and Diversity, 7: 349-358.

Lamb, D.; Erskine, P.; Parrotta, J.A. 2005. Restoration of degraded tropical forest landscapes. Science, 310:1628-1632. 
Leakey, A.D.B.; Press, M.C.; Scholes, J.D. 2003: High-temperature inhibition of photosynthesis is greater under sunflecks than uniform irradiance in a tropical rain forest tree seedling. Plant Cell and Environment, 26: 1681-1690.

Longworth, J.B.; Mesquita, R.C.G.; Bentos, T.V.; Moreira, M.P.; Massoca, P.E.S.; Williamson, G.B. 2014. Shifts in dominance and species assemblages over two decades in alternative successions in central Amazonia. Biotropica, 46:529-537.

Lovejoy, T.E.; Bierregaard Jr, R.O. 1990. Central Amazonian forests and the minimum critical size of ecosystems project. In: Gentry, A. (Ed.). Four Neotropical Rainforests. Yale University Press, New Haven, p.60-74.

Luizão, R.C.C.; Luizão, F.J.; Paiva, R.Q.; Monteiro, T.F.; Souza, L.S.; Kruijts, B. 2004. Variation of carbon and nitrogen cycling processes along a topographic gradient in a central Amazonia forest. Global Change Biology, 10: 92-600.

Lucas, R.M.; Honzák, M.; Amaral, I.; Curran, P.J.; Foody, G.M.; Amaral, S. 1998. Avaliação da composição florística, biomassa e estrutura de floresta tropical em regeneração: a contribuição do sensoriamento remoto. In: Gascon, C.; Moutinho, P. (Ed.). Floresta Amazônica: Dinâmica, Regeneração e Manejo. Editora INPA, Manaus, p.61-82.

Mesquita, R.C.G.; Ickes, K.; Ganade, G.; Williamson, G.B. 2001. Alternative successional pathways in the Amazon Basin. Journal of Ecology, 89: 528-537.

Mesquita, R.C.G.; Massoca, P.E.S.; Jakovac, C.C.; Bentos, T.V.; Williamson, G.B. 2015. Amazon rain forest succession: stochasticity or land-use legacy? BioScience, 65: 849-861.

Montgomery, R.A.; Chazdon, R.L. 2001. Forest structure, canopy architecture and light transmittance in tropical wet forests. Ecology, 82: 2707-2718.

Nazário, P.; Ferreira, S.A.N.; Rebouças, E.R. 2008. Germinação de sementes de Cynometra bauhiniifolia Benthan (jutairana) em função do dessecamento e da manutenção sob condição úmida. Acta Amazonica, 38: 439-444.

Norden, N.; Mesquita, R.G.C.; Bentos, T.V.; Chazdon, R.L.; Williamson, G.B. 2010. Contrasting community compensatory trends in alternative successional pathways in central Amazonia. Oikos, 120: 143-151.

Peńa-Claros, M.; Boot, R.G.A.; Dorado-Lora, J.J; Zonta, A. 2002: Enrichment planting of Bertholletia excels in secondary forest in Bolivian Amazon: Effect of cutting line width on survival, growth, and crown traits. Forest Ecology and Management, 161: 159-168.

Ranzani, G. 1980. Identificação e caracterização de alguns solos da Estação Experimental de Silvicultura Tropical do INPA. Acta Amazonica, 10: 7-41.

Romell, E.; Hallsby, G.; Karlsson, A.; Garcia, C. 2008. Artificial canopy gaps in a Macaranga spp. dominated secondary tropical rain forest-effects on survival and above ground increment of four under-planted dipterocarp species. Forest Ecology and Management, 255: 1452-1460.
Saldarriaga, J.G.; West, D.C.; Tharp, M.L.; Uhl, C. 1988. Long term chronosequence of forest succession in the upper Rio Negro of Colombia and Venezuela. Journal of Ecology, 76: 938-958.

Tavares, A.S. 1987. Revisão taxonômica do gênero Cynometra L. (Caesalpinaceae) da Amazônia. Master's dissertation, Instituto Nacional de Pesquisas da Amazônia/Fundação Universidade do Amazonas, Brazil. 141p.

Tavares, A.S.; Silva, M.F. 1992. Distribuição geográfica do gênero Cynometra L. (Caesalpinaceae) no mundo. Acta Amazonica, 22: 17-22.

Toledo, J.J.; Magnusson, W.E.; Castilho, C.V.; Nascimento, H.E.M. 2011. How much variation in tree mortality is predicted by soil and topography in Central Amazonia? Forest Ecology and Management, 262: 331-338.

Uhl, C.; Buschbacher, R.; Serrão, E.A.S. 1988. Abandoned pastures in Eastern Amazonia. I. Patterns of plant succession. Journal of Ecology, 76: 663-681.

Uchida, T.; Campos, M.A.A. 2000. Influência do sombreamento no crescimento de mudas de cumaru (Dipteryx odorata (Aubl.) Willd.-Fabaceae, cultivadas em viveiro. Acta Amazonica, 30: 107-114.

Whitmore, T.C. 1989. Canopy gaps and the two major groups of forest trees. Ecology, 70: 536-538.

Williamson, G.B.; Longworth, J.B.; Bentos, T.V.; Mesquita, R.C.G. 2012. Convergence and divergence in alternative successional pathways in Central Amazonia. Plant Ecology and Diversity, 7: 341-348.

Wilkinson, L. 2007. The System for Statistics, version 12.0 for Windows. SYSTAT Inc.

Wittmann, F.; Schoengart, J.; Brito, J.M.; Oliveira-Wittmann, A.; Guillament, J.L.; Piedade, M.T.F.; Parolin, P.; Junk, W.J. 2010. Manual de árvores da várzea da Amazônia Central: taxonomia, ecologia e uso. Editora INPA, Manaus. 286p.

Xavier, G.P.L.; Silveira, A.J. 2001. Produção de sabão de sementes de frutos regionais. Revista Virtual de Iniciação Acadêmica da UFPA Belém, 1: 1-4.

Yavitt, J.B.; Wright, S.J. 2008. Seedling growth responses to water and nutrient augmentation in the understory of a lowland moist forest, Panama. Journal of Tropical Ecology, 24: 19-26.

Yavitt, J.B.; Battles, J.J.; Lang, G.E.; Knight, D.H. 1995. The canopy gap regime in a secondary Neotropical forest in Panamá. Journal of Tropical Ecology, 11: 391-440.

Zau, M.D.L.; Vasconcelos, R.P.; Giacon, V.M.; Lahr, F.A.R. 2014 Avaliação das propriedades química, física e mecânica de painéis aglomerados produzidos com resíduo de madeira da Amazônia - Cumaru (Dipteryx Odorata) e resina poliuretana à base de óleo de mamona. Polimeros, 24:726-732.

RECEIVED: $01 / 05 / 2020$

ACCEPTED: $15 / 06 / 2020$

ASSOCIATE EDITOR: Robyn Burnham 